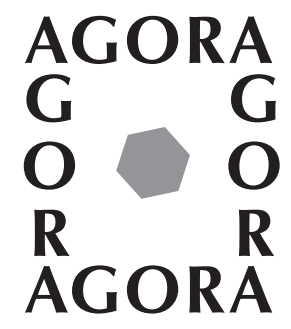

AGORA is a lighter channel of communication between readers and contributors; it aims to stimulate discussion and debate, particularly by presenting new ideas and by suggesting alternative interpretations to the more formal research papers published in WEB ECOLOgY and elsewhere. A lighter prose is encouraged and no summary is required. Formal research papers, however short, will not be considered.

\title{
On Verdansky’s biosphere
}

\author{
Jorge P. Cancela da Fonseca (jorge.cancela@wanadoo.fr), CNRS and Université Paris 7-Denis Diderot, \\ Laboratoire de Biologie végétale et d'Ecologie forestière, F-77300 Fontainebleau, France.
}

\begin{abstract}
Vladimir Ivanovitch Vernadsky was a Russian mineralogist and crystallographer by training (St. Petersburg Univ.). He was born in St. Petersburg, on the 12th of March 1863, and died on the 6th of January 1945, in Moscow.

About 1910, he became a geochemist and later on a founding father of Biogeochemistry, due to his concern with the "questions related to the importance of life on the geological history of the Earth". This new direction was the result of his field observations, of his broad mineralo-geological knowledge, and his studies, from 1917, on the phenomena of life in the biosphere, confirmed by many of his readings, like the book by Clarke (1908), "The Data of Geochemistry", and in particular the "Hydrogéologie" of J. B. Lamarck (1802).

From this, and knowing the Lamarck work, and the Suess work and the definition of a biosphere he redefined and worked the biosphere concept in larger biogeochemical terms.
\end{abstract}

"The biosphere is distinguished as the domain of life, but
also and more fundamentally, as the region where changes
due to incoming radiation can occur." W. I. Vernadsky
(1945), The biosphere and the noösphere.
Vladimir Ivanovitch Vernadsky (1863-1945) was born
in St. Petersburg, on the 12th of March 1863, and died on
the 6th of January 1945, in Moscow.
By training at St. Petersburg Univ. (1881-1885), he
was primarily a crystallographer and a mineralogist. At the
University he had been influenced by his professors, the
chemists D. Mendeleev and A. Butlerov, and particularly
by the mineralogist V. V. Dokuchaev, Professor of Crystal-
lography and Mineralogy, and the founding father of Soil
Science, for whom he had been assistant (Mauguin 1945 ,
Grinevald 1997 a, b). There, he started and developed his
scientific research, and submitted his Magister's and Doc-
tor's theses (1891 and 1897$)$, being from 1885 to 1890 the
Keeper of the Mineralogical Cabinet of the University. In
1890 he settled in Moscow, becoming Professor of Crystallography and Mineralogy at the University (from 1891 to 1911) and Keeper of its Mineralogical Cabinet. At the same time he was Manager of the Mineralogical Department of the Geological Museum of the Academy of Sciences in Moscow (1906-1914) and in St. Petersburg (1911-1915). In 1911 he resigned from Moscow Univ. for political reasons, and moved back to St. Petersburg. From 1918 to 1921 he was in Ukraine, and read biogeochemistry at the Univ. of Kiev and Simferopol (Tauria Univ.), becoming Rector of the Ukrainian Univ. and the first President of the Ukrainian Academy of Sciences, in Kiev. In 1921 he returned to Petrograd (St. Petersburg). As the Academy of Sciences moved from Leningrad (St. Petersburg) to Moscow in 1935, he settled again there until his death. From 1884 (including the time as a student) until 1936, he was sent abroad for visiting, research and teaching missions of mineralogy and geochemistry, mainly in 
Europe: Austria-Hungary, Germany, Switzerland, France, Italy, Denmark, Netherlands, Czechoslovakia, Sweden, Norway, Great Britain, Canada, and USA. Two important scientific missions were in France (Paris) in 1898-1900, and 1922-1926; during the first mission, to study the synthesis of minerals, he frequented the laboratories of Le Chatelier (Ecole des Mines de Paris) and Fouqué (Collège de France). The aim of the second mission was, at the invitation of the director of the Sorbonne, Paul Appell, for "reading a course in geochemistry" and also for doing research work at the Mineralogical laboratory of Alfred Lacroix, at the Museum National d'Histoire Naturelle and in Pierre Curie Radium Institute. Vernadsky was also very keen on the Philosophy and History of Science.

His scientific career was subsequently devoted to mineralogical problems in Russia, principally those in relation to the increasing knowledge of Russian mineral resources, of which the radioactive minerals, at least from 1907 (see e.g. 1910 reports: "On the necessity for studying the radioactive minerals of the Russian empire", and "Topical targets in the area of radium research"), and those of geochemistry, from 1910. His initiatives led to the creation of the Commission on Radium (1910), the Commission for the Study of Natural Productive Forces (KEPS) (1915) and of the Biogeochemical Laboratory (1928) of the Academy of Sciences, and of some other commissions, becoming their Chairman. Due to his national and international renown as a scientist he was elected member of a number of scientific national and international societies and elected Academician of the Academy of Sciences of, successively, St. Petersburg-Moscow-USSR (extraordinary member, 1908; ordinary member, 1912), Czechoslovakia (foreign member, 1926), and Paris (corresponding member, 1928).

This summary up of his biography is compiled from different sources, namely: Mauguin (1945), Guegamian (1981), Krout (1983), Ghilarov (1995), Grinevald (1997a, b), and Anon. (1997).

"The idea according to which Geochemistry would be a science devoted to the history of the chemical elements", the atoms, of the Earth, "was born in Moscow about the first decade of the 20th century" (Vernadsky 1945a). Nevertheless, the word "geochemistry" was introduced by F.W. Clarke in 1908 (The Data of Geochemistry), though it was coined much earlier, in 1838, by J. Schönbein whose ideas were largely forgotten until 1929-31 (Vernadsky 1945a).

At that time, Vernadsky became one of the pioneer geochemists (Mauguin 1945, Grinevald 1997a, b), and more particularly the founding father of Biogeochemistry (Guegamian 1981). This new direction was the result of his field observations, of his broad mineralo-geological knowledge, and his studies (from 1917) on the phenomena of life in the biosphere (Vernadsky 1924a, 1929), confirmed by many of his readings (Deléage 1997), such as the books of Clarke and especially the "Hydrogéologie" of J. B. Lamarck (1802) (Guegamian 1981).
Based on his lectures on geochemistry delivered in 1922-1923 at the Univ. of Paris (La Sorbonne), he published, in French, the book "La géochimie [Geochemistry]" (Vernadsky 1924a), latter translated into Russian ("Ocherky geokhimii [Essays on Geochemistry]" 1927) and into German ("Geochemie in ausgewahlten Kapiteln" 1930). In this book the concept of the biosphere was already mentioned.

One is tempted to make a parallel between his interest in the "questions related to the importance of life in the geological history of the Earth" (Guegamian 1981) and the assertion of his uncle Y. M. Korolenko that "The Earth is an organism" (Balandin 1979, Lovelock 1988, Grinevald $1997 \mathrm{a}, \mathrm{b}$ ), that is "a living being". Already, (at a meeting of the Royal Society of Edinburgh in 1785), the geologist James Hutton had considered that the Earth, "this planetary body, ... may be termed a living world" (Hutton 1788), i.e. as a superorganism (Lovelock 1988, Deléage 1997).

From this, and knowing Lamarck's work (1802), and Suess' work and a definition of biosphere (1875), he redefined and worked the biosphere concept in larger biogeochemical terms (Vernadsky 1924a, 1926a, 1929). He became, thus, the founding father of the science of the biosphere: Biospherology (Guegamian 1980, 1981) or Global Ecology (Rambler et al. 1989).

The Biosphere concept, an idea put forward by Vicq d'Azir [1748-1794 (Moreau 1805); see Vernadsky (1924a p. 43)] and overall by Lamarck ("Hydrogéologie" 1802), was defined later by Suess ("Die Entschung der Alpen, [The Origin of the Alps]" 1875) "as a specific, life-saturated envelope of the Earth's crust" (Vernadsky 1924a pp. 6061, 1926a/1998, 1929\$68), and redefined and developed by Vernadsky (1926a, 1929). Then, soon after his sojourn in Paris, he published (in Russian), in Leningrad, the book "Biosfera" (1926). Three years later, being in Paris in 1929, Vernadsky revised "La biosphère" and translated it into French. In his preface, the author emphasizes that this book "follows [his] essay on "La géochimie", where the corresponding references are indicated", and defines its aim, "to draw the attention of naturalists, geologists, and above all biologists to the importance of a quantitative study of the relationships between life and the chemical phenomena of the planet". This French edition was recently reedited (Vernadsky 1929/1997) as well as the Russian edition, in English (Vernadsky 1926a/1998). In the preface of the Russian edition Vernadsky points out that the biosphere had not been "adequately treated [...] as a whole, and $[\ldots .$.$] viewed [\ldots]$ as a single orderly manifestation of the mechanism of the uppermost region of the planet - the Earth's crust", organisms (i.e. life) being found only there (cf. Vernadsky 1926a/1998 and 1929 \$19).

According to Vernadsky (1926a/1998 and $1929 \$ \$ 8$, 10), "The biosphere may be regarded as a region of transformers that convert cosmic radiations into active energy" [...], particularly "the action of solar radiation [...], the bio- 
sphere being largely the product of this radiation" as well as the living matter. Thus, "the importance of radiant solar heat for the existence of life is incontestable; so, too, is the transformation of the sun's thermal radiation into mechanical, molecular [...], and chemical energy." Thus, "if life were to cease the great chemical processes connected with it would disappear, both from the biosphere and probably also from the crust. All minerals in the upper crust - the free alumino-silicious acids (clays), the carbonates (limestones and dolomites), the hydrated oxides of iron and aluminium (limonites and bauxites), as well as hundreds of others, are continuously created by the influence of life" (Vernadsky 1926a/1998 and $1929 \$ \$ 20,66,159)$. That way, the Biosphere is the result of the active interaction between living organisms, the living matter, and the inert mineral matter surrounding it, in the sense of an holistic feedback system.

More recently, the idea that the Earth is a living organism was again developed by Lovelock (1979), who put forward the Gaia hypothesis, which "postulates that the physical and chemical condition of the surface of the Earth, of the atmosphere, and of the oceans has been and is actively made fit and comfortable by the presence of life itself". He defines Gaia "as a complex entity involving the Earth's biosphere, atmosphere, oceans, and soil; the totality constituting a feedback or cybernetic system which seeks an optimal physical and chemical environment for life on this planet". This hypothesis rejoins that of Vernadsky which Lovelock didn't know when he thought about Gaia (Lovelock 1988).

Thus, the biosphere is a homeostatic system, constituted by the biota and its environment, "that opposes changes unfavorable for life" (Margulis and Lovelock 1989), in other words it includes all ecosystems and their interfaces. Some authors prefer to call it ecosphere (Cole 1953), in the sense of a more operational ecological system, but, that way, biosphere looses its rather important universal, global sense. Life on the Earth interacts with its environment, and changes it, affecting profoundly the atmosphere (Margulis and Lovelock 1989) as well as some components of the lithosphere (Vernadsky 1926a/1998 and 1929 \$20, Lapo 1982). As Vernadsky tells us, "the atmosphere is not an independent region of life" but a product of the biosphere, of life (Vernadsky 1926a/1998 and $1929 \$ \$ 50$, 120). Actually, this is more widely accepted (cf. McNemanin in Vernadsky 1926a/1998 \$50).

Already Lamarck, in 1802, had put forward a theory in the same sense: "Without exception, the raw compounds which form most of the earth's external crust and continuously modify it by their changes all result from the remains and residues of living organisms" As a system, the biotic part of the biosphere is formed by the integrated plant and animal communities (the biomes), and the inert part of it, its fundamental environment or milieu, formed by the atmospheric gases and water, the lithosphere minerals and rocks, and the hydrosphere, all under the influence of the basic solar energy (sun radiation) and of human-controlled energy (fuel energy, human labour, etc.).

One year after the publication of "La géochimie", and prior to the publication of his biosphere books, Vernadsky wrote, in French, a Memoir (1925a) on "La matière vivante dans la biosphère [The living matter in the biosphere]", published in Russian only in 1994 (Guegamian pers. comm.), where he states the way he developed his research aiming to answer questions about "the transmission of living matter at the Earth's surface", questions which he analyses in this manuscript and in several papers over the following years (Vernadsky 1925a, 1926b, c, 1927, 1930, Cancela da Fonseca unpubl.).

According to his geochemical point of view, Vernadsky divided his book "The Biosphere" into two essays, supposedly independent, "The Biosphere in the Cosmos" (Part one) and "The Domain of Life" (Part two). However, they are linked by the phenomena of life: "the chemistry of the biosphere is completely impregnated by life's phenomena, by the cosmic energy absorbed by it, and cannot be understood even in its more general traits without bringing to light the place occupied by the living matter in the mechanism of the biosphere" (Vernadsky $1929 \$ 62$ ).

Also, the Cosmos, and by consequence the Earth which is part of it, owes its unity to the set of "chemical elements", and its diversity to the distribution, in space and time, of the different groups formed by these elements, as Vernadsky says (1924a, pp. 1-6). Vernadsky (1924a, pp. 22, 2628) divided the known chemical elements into six groups, the Group III, "Cyclic or organogenic elements", contains the largest number of chemical elements (ca 46\%); they are the most important to characterize the Biosphere; their "geochemical history [...] can be expressed in cycles", i.e. each chemical element forms renewable combinations which after more or less long and complex changes come back to the first combination, starting again a new cycle (Vernadsky 1924a, p. 26). The concept of geochemical cycle was introduced in geochemistry by Vernadsky (Allègre and Michard 1973), it corresponds "to the changes of the chemical elements equilibrium in the different Earth envelopes during a long enough geological time" (Vernadsky 1924a, pp. 72-73).

Furthermore, Vernadsky distinguishes in the Earth's crust four stable systems or "modes of occurrence" of the chemical elements, the "chemical phenomena of the living organisms vivants, of the living matter", being one of them (Vernadsky 1924a, pp. 35-36, 1926a/1998 and 1929 $\$ 86)$. From these, living matter, the new geochemical parameter introduced by Vernadsky, is the most important, because it "transforms the radiant energy of the sun into the active chemical energy of the biosphere" (Vernadsky $1926 \mathrm{a} / 1998$ and $1929 \$ 11$ )

Thus, according to Vernadsky (1924a, p. 42), "from the geochemical point of view, the living organisms are not an occasional event in the chemical mechanism of the earth's crust; they form its most essential and closed part. They are 
indissolubly tied up with the inert materials of the crust, to the minerals and to the rocks", i.e., to their environment. To him the biologists "in studying the living organisms as something quite distinct from the environment, [...] they do not study a natural body, but an ideal product of their thinking" (Vernadsky 1924a, p. 43). In conclusion, as he states in "The Biosphere": "Life is [...] not an external or accidental phenomenon of the Earth's crust. It is closely bound to the structure of the crust, forms part of its mechanism, and fulfills functions of prime importance to the existence of this mechanism. Without life, the crustal mechanism of the Earth would not exist" (Vernadsky $1926 a / 1998$ and $1929 \$ 21)$.

"The action of the living organisms on the history of the chemical elements of the earth's crust is, for the most part, a product of their nutrition and of their respiration." (Vernadsky 1924a, pp. 45, 47-48, 1926a/1998 and 1929 $\$ 91)$. Thus, "the emission of free oxygen by organisms, by chlorophyll plastids, remains really its main source, and the quantity of free oxygen gives a measure of the geochemical work of the organisms. [...] This fact shows us the difference between the manifestation of life in the phenomena of biology and of geochemistry. We can see first of all that life acts by energy, the amount and the composition of its matter, and afterwards that the organisms as such disappear due to the importance of the phenomena studied. We see then only their total effect." (Vernadsky 1924a, pp. 52-53). The biogenic origin of the atmospheric oxygen was first put forward by Vernadsky (cf. McNemanin in Vernadsky 1926a/1998 \$115) as well as the origin of the ozone screen: "Life creates both the free oxygen in the Earth's crust, and also the ozone that protects the biosphere from the harmful short-wavelength radiation of celestial bodies". (Vernadsky 1926a/1998 \$115).

Vernadsky (1924a, p. 54) goes on: "In geochemistry life shows itself through the overall action of millions of isolated organisms, through them as a group. [...] To be able to study this living group in geochemistry we may express it with the same terms, with the same logical parameters than the other deposit modes of the chemical elements to which we compare it" (minerals, rocks, etc.). "That is, we may express the group of organisms exclusively in relation to their weight, their chemical composition and their energy." That way, the new parameter introduced by Vernadsky (1924a, pp. 54-55, 1926a/1998 and $1929 \$ 11$ ), the "living matter" i.e. "the total group of organisms, expressed in weight, in chemical elements, in energy", is of capital importance. It can be separated, as organism groups are morphologically, and physiologically, different (species, genera etc.) in "homogeneous living matters, constituted by the set of individuals, of organisms of the same species or the same race", and in "heterogeneous living matters where the elements of the set - the organisms - belong to different species or races". "The whole set of living organisms [heterogeneous living matter] [...] forming living $\mathrm{Na}$ ture" (Vernadsky 1924a, p. 55). That way, as it was indicat- ed beforehand, the living matter (i.e. Life) "creates innumerable new chemicals by photosynthesis", like "all minerals in the upper Earth's crust" (Vernadsky 1926a/1998 and $1929 \$ \$ 11,20,66)$. Later, Vernadsky redefined the different types of matter in the biosphere (Vernadsky 1965 in Lapo 1982, and Ghilarov 1995), the most characteristic being: "a) Living matter: the totality of all living organisms; b) Biogenic matter: that which is created and transformed by the actions of living organisms (e.g. coal, oil, limestone); c) Inert matter: formed by processes without any action of organisms; d) "Bioinert" matter: formed both by the activity of organisms and by purely physicochemical processes (e.g. soil, the water of oceans, lakes and rivers)" (Ghilarov 1995).

Vernadsky sees, thus, the planet Earth as a geochemical entity, that is made up by the same set of chemical elements variously distributed on the different envelopes (cover layers) of our planet: the lithosphere, the hydrosphere, the atmosphere and the biosphere. These spheres are but apparently independent; their various interactions reach their highest level with the primordial role of the biosphere as an active participant in the geochemical cycles, not to say to control them. This raises the question of the boundaries of the biosphere. These are established by the boundaries of life. "The upper limit is determined by the radiant energy which eliminates life", the ozone screen determining thus this "potential upper limit". Nevertheless, living organisms have been found at lower altitudes, normally between 3 and $5 \mathrm{~km}$, sometimes at the top of the highest mountains (Himalaya) and exceptionally at the limit of troposphere (9-13 km) (Vernadsky 1926a/1998 and $1929 \$ \$ 113,117-118)$. "The lower limit is formed by temperatures so high that life becomes impossible. ... It is unlikely that the lower limit of the biosphere exceeds a depth of 2.5 to $2.7 \mathrm{~km}$ on land, and 5 to $5.5 \mathrm{~km}$ in the oceans". (Vernadsky 1926a/1998 and $1929 \$ \$ 113,121$ ).

The notion of living matter is then placed at the interface of the geological and biological sciences, and is also an important notion in ecology. It constitutes the essential component of the biosphere (Vernadsky 1926a/1998 1929, cf. Guegamian 1980, 1981).

For Vernadsky, an important characteristic of living matter is its capacity of dispersion over the Earth's surface, "movement caused by the multiplication of the organisms" composing it "which takes place [...] with a specific intensity related to that of the solar radiation" (Vernadsky 1925a $\$ 64,1926 a / 1998$ and $1929 \$ 24)$. This theme is a fundamental one in ecological dynamics (population, community and ecosystem dynamics).

Living matter continually exchanges chemical elements with its non-living environment (Vernadsky 1926a/1998, $1926 \mathrm{~b}$ and $1929 \$ 11)$. Evidently, the weight of the homogeneous living matter varies greatly. However, the total mass of the living matter, as well as its chemical composition, "seems to be stable all along the geological time" (Vernadsky 1924a, p. 284, 1925a $\$ \$ 3-5)$. Nevertheless, al- 
though the hypothesis of biosphere steady-state is often put forward by the biogeochemists in their elaboration of biogeochemical cycle models, this hypothesis in many cases seems not to be valid, principally "during transient periods of rapid change. [...] The biosphere is always changing in response to cycles" (Schlesinger 1997). Maybe it is more accurate to state that we are in presence of a stationary equilibrium, the values fluctuating around a mean value with time (cf. Vernadsky 1924a, p. 287, 1925a \$5).

The value of the total biomass of the living matter in the biosphere given by Vernadsky, $5.1 \times 10^{20}$ grams (1924a, p. 281) or in order of $10^{20}-10^{21} \mathrm{~g}$ (1924a, p. 262, 1925 a $\$ \$ 2-3,1929$ and 1997 a $\$ 46$ ), is of the same order of mass of the free oxygen in the biosphere, $1.5 \times 10^{21}$ (Vernadsky 1924a, pp. 49-50, 1925a A.1 \$7), and comes near of that of the Earth, $6 \times 10^{27} \mathrm{~g}$ (Fyfe 1992). However is valuation is relativelly higher than that of other authors: actually ca $5 \times 10^{18} \mathrm{~g}$ of fresh biomass, and ca $18,41 \times 10^{17}$ $\mathrm{g}$ of dry biomass (Taube 1992$)\left(12.9 \times 10^{17} \mathrm{~g}\right.$, according to Duvignaud 1980).

The chemical composition of the terrestrial part of the biosphere consists thus of three groups of elements: 1) carriers of life elements, H, O, C, N, P, S (96.74\%); 2) important elements, $\mathrm{Na}, \mathrm{Mg}, \mathrm{Cl}, \mathrm{K}, \mathrm{Ca}, \mathrm{Fe}(2.93 \%)$; and 3) less abundant elements, F, Si, V, Cr, Mn, Co, Cu, Zn, Se, Br, Sn, I (0.07\%) (Taube 1992) (Table 2). With the exception of $\mathrm{Br}$ and I (dispersed elements), all these elements are cyclic, organogenic elements (Vernadsky 1924a, p. 22) (Table 1).

The chemical composition of the homogeneous living matter, from the geochemical point of view, is one of its specific characteristics like all their morphological or physiological characteristics (Vernadsky 1924a, pp. 52-60, 1930). This composition is given in a more accurate way by the percentage of the number of atoms of the same chemical element than by the percentage of its weight (Vernadsky 1924b, 1925a \$4, 1930, cf. Taube 1992). Besides, Vernadsky (1925a $\$ 4,1930)$ considers that "each species or race has a specific composition which is its own and that separates it from the other homogeneous living matters" (cf. Vernadsky and Vinogradoff 1931). He goes further and suggests that the morphological differences between the living organisms "are due to specific molecules developed by each organism and which are but its own" (Vernadsky 1930). This idea was also suggested in relation with the trophic behaviour of soil microarthropods, independently, by Cancela da Fonseca (1982, Cancela da Fonseca and Poinsot-Balaguer 1983, Rihani et al. 1995). This implies that Vernadsky was ahead of his time, molecular genetics not being really developed until after the molecular structure of the DNA was found in 1953 (Watson and Crick 1953a, b). The DNA is not only the guardian of the genetic code but also responsible for transmitting, through the RNA, the codes required to the elaboration of the proteins which control the characteristics of the living beings (Ridley 1993).

Two of the elements of the chemical composition of the biosphere have (and have had) a primordial rôle on its dynamic equilibrium and on its evolution: carbon and oxygen, as indispensable agents to photosynthesis $\left(\mathrm{CO}_{2}\right)$ and to respiration $\left(\mathrm{O}_{2}\right)$, and as characteristic components of living matter (Vernadsky 1924a, Allègre and Michard 1973, Lovelock 1979, 1988). Then, all living matter is directly or indirectly dependent on organic matter, (photoor chimio-) synthesized by autotrophic organisms, namely green plants.

Carbon, one of the most important chemical elements of the biosphere, is globally estimated, either between 5.0 $\times 10^{19}$ and $5.0 \times 10^{20} \mathrm{~g}$ (Vernadsky 1924a, p. 282), or, in terms of phytomass, ca $6.0 \times 10^{17} \mathrm{~g}$ (Duvignaud 1980, Schlesinger 1997). The other important element of the biosphere, free oxygen, "created by life", is estimated to 1.5 $\times 10^{21} \mathrm{~g}$ (Vernadsky 1924a, pp. 49-50, 1926b), or even to $1.2 \times 10^{21} \mathrm{~g}$ (Schlesinger 1997).

Yet, according to Vernadsky (1925a \$7), the mass and chemical composition of living matter, the only two parameters indicated beforehand, are not enough to explain the geochemical importance of living matter. A third pa-

Table 1. Chemical element groups (Vernadsky 1924a, Table III).

\begin{tabular}{llcc}
\hline Chemical element groups & Chemical elements & $\mathrm{n}$ & $\%$ \\
\hline I. Precious elements & $\mathrm{He}, \mathrm{Ne}, \mathrm{Ar}, \mathrm{Kr}, \mathrm{Xe}$ & 5.44 \\
II. Neutral elements & $\mathrm{Ru}, \mathrm{Rh}, \mathrm{Pd}, \mathrm{Os}, \mathrm{Ir}, \mathrm{Pt}$ & 6 & 6.52 \\
III. Cyclic elements & $\mathrm{H}, \mathrm{Be}$, , B, C, N, O, F, Na, Mg, Al, Si, P, S, Cl, K, Ca, & 42 & 45.65 \\
& $\mathrm{Ti}, \mathrm{V}, \mathrm{Cr}, \mathrm{Mn}, \mathrm{Fe}, \mathrm{Co}, \mathrm{Ni}, \mathrm{Cu}, \mathrm{Zn}, \mathrm{Ge}$, , As, Se, Sr, Mo, & \\
& $\mathrm{Ag}, \mathrm{Cd}, \mathrm{Sn}, \mathrm{Sb}, \mathrm{Te}, \mathrm{Ba}, \mathrm{W}, \mathrm{Au}$ ?, Hg, Tl, Pb, Bi & 9 & 9.78 \\
IV. Dispersed elements & $\mathrm{Li}, \mathrm{Sc}, \mathrm{Ga}, \mathrm{Br}, \mathrm{Rb}, \mathrm{Y}, \mathrm{In}, \mathrm{I}, \mathrm{Cs}$ & 7 \\
V. Strongly radioactive elements & $\mathrm{Po}, \mathrm{Nt}, \mathrm{Ra}, \mathrm{Ac}, \mathrm{Th}, \mathrm{Pa}, \mathrm{U}$ & 7.6 \\
VI. Elements of the rare earths & $\mathrm{La}, \mathrm{Ce}, \mathrm{Pr}, \mathrm{Nd}, \mathrm{Sm}, \mathrm{Eu}, \mathrm{Gd}, \mathrm{Tb}, \mathrm{Dy}, \mathrm{Ho}, \mathrm{Er}, \mathrm{Tm}, \mathrm{Yb}, \mathrm{Lu}$ & 14 & 15.22 \\
\hline
\end{tabular}


Table 2. Elementary composition of the "terrestrial" biosphere (Taube 1992, Table 17).

\begin{tabular}{|c|c|c|c|}
\hline \multirow[t]{2}{*}{ Atomic number } & \multirow[t]{2}{*}{ Element } & \multicolumn{2}{|c|}{ Biomass composition } \\
\hline & & Atomic & In weight \\
\hline \multicolumn{4}{|l|}{ Carriers of life } \\
\hline 1 & $\mathrm{H}$ & 62.9 & 10 \\
\hline 8 & $\mathrm{O}$ & 24.8 & 63 \\
\hline 6 & $\mathrm{C}$ & 10.5 & 20 \\
\hline 7 & $\mathrm{~N}$ & 1.1 & 2.5 \\
\hline 15 & $\mathrm{P}$ & 0.2 & 1.1 \\
\hline 16 & $S$ & 0.03 & 0.14 \\
\hline \multicolumn{4}{|c|}{ Important elements } \\
\hline 11 & $\mathrm{Na}$ & 0.02 & 0.1 \\
\hline 12 & $\mathrm{Mg}$ & 0.02 & 0.1 \\
\hline 17 & $\mathrm{Cl}^{\circ}$ & 0.03 & 0.16 \\
\hline 19 & $\mathrm{~K}$ & 0.02 & 0.11 \\
\hline 20 & $\mathrm{Ca}$ & 0.4 & 2.45 \\
\hline 26 & $\mathrm{Fe}$ & 0.015 & 0.01 \\
\hline \multicolumn{4}{|c|}{ Less abundant elements } \\
\hline 9 & $\mathrm{~F}$ & - & 0.004 \\
\hline 14 & $\mathrm{Si}$ & - & 0.03 \\
\hline 23 & $\mathrm{~V}$ & - & - \\
\hline 24 & $\mathrm{Cr}$ & - & - \\
\hline 25 & $\mathrm{Mn}$ & - & 0.03 \\
\hline 27 & Co & - & - \\
\hline 29 & $\mathrm{Cu}$ & - & 0.0002 \\
\hline 30 & $\mathrm{Zn}$ & - & 0.0001 \\
\hline 34 & $\mathrm{Se}$ & - & - \\
\hline 35 & $\mathrm{Br}$ & - & 0.0003 \\
\hline 50 & $\mathrm{Sn}$ & - & - \\
\hline \multirow[t]{2}{*}{53} & I & - & 0.0001 \\
\hline & Total & 100.0 & 100.0 \\
\hline
\end{tabular}

rameter must be taken into account, the geochemical energy, that is "the inherent capacity of its mechanism to produce in a certain time a determined mass of matter of which the chemical composition is constant. [...] This energy manifests itself by the intensity of the elaboration of new living beings, that is by the different number of individuals which are projected into the biosphere, at the same time by different living species". Furthermore, "it is the reproduction that presents the mechanism by which this energy manifests itself, it is by the multiplication of the organisms that it can be measured" (Vernadsky 1925a \$7). All organisms take this energy from the solar radiant energy captured by the green plants. Therefore, the living-matter energy is of cosmic origin. The flow of energy emitted by the sun is ca $4 \times 10^{26} \mathrm{~W}$, from which only $1.75 \times 10^{17} \mathrm{~W}$ $\left(4.3 \times 10^{-10} \%\right)$ reaches the Earth, the solar radiation flux reaching the outer terrestrial atmosphere, the "solar constant", being then on average of $1367 \mathrm{~W} \mathrm{~m}^{-2}$ of the cross sectional area of the Earth (at equator, $S=\pi r^{2}=1.275 \times 10^{14}$ $\mathrm{m}^{2}$ ), i.e. ca $342 \mathrm{~W} \mathrm{~m}^{-2}$ of the corresponding real surface $\left(\mathrm{S}=4 \pi \mathrm{r}^{2}=5.10065 \times 10^{14} \mathrm{~m}^{2}\right)$; from this amount of energy,
$170 \mathrm{~W} \mathrm{~m}^{-2}$ (ca 50\%) arrives at the Earth's surface and are available to plants (Taube 1992), but only ca $18 \mathrm{~W} \mathrm{~m}^{-2}$ (5\%) can be utilized for photosynthesis (cf. Anderson 1981). Thus, "the energy balance of the planet as a cosmic system depends on living matter" (Guegamian 1980).

The geochemical action of the organisms manifests in this way by reproduction (cf. Vernadsky 1924a, pp. 264$275,1925$ a $\$ 7,1926 a / 1998$ and $1929 \$ \$ 24,26)$ and can be measured by their multiplication in the biosphere, multiplication which follows "geometric progression laws" (Vernadsky 1925a \$13, 1926a/1998 and $1929 \$ \$ 24,26)$.

According to Vernadsky (1925a $\$ \$ 25-26)$, among the data important to estimate the geochemical energy there are the average weight of the adult organisms and the type of reproduction: a) potential (innate); b) optimum (in optimal conditions of life); and, c) average real (in real conditions of the organism's environment). These reproduction types play an important role in the study of multiplication because they permit us "to compare quantitatively the geochemical energies of different organisms" and to express "the maximum chemical energy of each species” (Vernadsky 1925a \$27). 
Furthermore, Vernadsky (1925a \$26, 1926a/1998 and $1929 \$ 32$ ) says that a good way to measure the reproduction strength of an organism is to find out the number of its generations per day $(\Delta)$, a number that he considers constant and characteristic of each species in the same environmental conditions.

In fact, the real reproduction rate is somewhat dependent on the population density (Vernadsky 1926a/1998 and 1929 \$36): e.g. it was observed several times that to a higher density corresponds a fall in the reproductive values (Vernadsky 1925a A.1\$6). This is the situation that can be observed as the result of intraspecific competition above a threshold value of the density (cf. Odum 1959, Begon et al. 1996).

In 1925, Vernadsky (1925a \$62) points out that, in his time, the link between the astronomical phenomena, like the sun's thermal and chemical radiation, and biological phenomena, like the multiplication of living beings, was not taken into account "in the scientific construction of the Universe". Nevertheless, thanks to his biochemical approach of the biosphere, supported by Lindeman (1942) and Hutchinson (1944, 1970), the study of this type of link was developed, particularly, during the "International Biological Program" (IBP; 1957 -1972). It is also the basis of the Gaia theory of Lovelock $(1979,1988)$.

Another interesting point developed by Vernadsky $(1925$ a $\$ \$ 62-65)$ is the analogy drawn between the movement of masses in astronomy and biological "movement" represented by the multiplication of the living beings; movement produced by respiration (gaseous exchange), nutrition, growth and metabolism in general (Vernadsky 1926c). Moreover, he shows that "the increasing of living matter is logically similar to the gaseous pressure" (Vernadsky 1925a \$64,1925b, 1926a/1998 and $1929 \$ 24)$; a question he developed already beforehand (Vernadsky 1924a, pp. 264-265). However, he prefers to represent this phenomenon of multiplication in terms of "speed of transmission of life" (Vernadsky 1925a \$65, 1926a/1998 and $1929 \$ \$ 30-31)$. Then, through multiplication, each organism will be able to colonize the whole Earth's surface if the environmental conditions are favorable (Vernadsky 1925a \$14). However, if the influence of external factors over the organism's development is very important, the action of internal ones is essential (cf. Perelman in Vernadsky $1926 a / 1998 \$ 32)$.

Taking as example the multiplication of the Protista "which reproduces itself by simple division of each cell", the geometrical progression that gives the multiplication of each living being is, according to Vernadsky (1925a \$68, $1926 \mathrm{a} / 1998,1926 \mathrm{~b}, \mathrm{c}$, and $1929 \$ 32$ ), a geometrical progression of ratio $\mathrm{Q}=2$ :

$$
\mathrm{N}_{\mathrm{n}}=2^{\mathrm{n} \Delta}
$$

where, $\mathrm{N}_{\mathrm{n}}$ - is the "number of individuals formed by this method in n days", from implicitly only one individual,
$\mathrm{N}_{\mathrm{o}}=1 ; \mathrm{n}$ - the "number of days from the beginning of the process", and $\Delta-$ the "number of generations per day", which characterizes the intensity of the multiplication.

This formula corresponds then to the classical equation of geometrical progression of ratio $\mathrm{Q}$ and first term $\mathrm{N}_{\mathrm{o}}$ (Déplanche 1991):

$$
\mathrm{N}_{\mathrm{t}}=\mathrm{N}_{\mathrm{t}-1} \mathrm{Q} \text { or } \mathrm{N}_{\mathrm{t}}=\mathrm{N}_{0} \mathrm{Q}^{\mathrm{t}}
$$

Nevertheless, Vernadsky (1925a) indicates that the formula such as it is, is rather restrictive, since it takes only into account the cases where $\Delta$ represents the number of doublings of the individuals. However, it gains in generalisation if $\Delta$ is a fraction which represents "the fraction of doublings measured in days".

Finally, the equation given by Vernadsky is the one that in the study of the (discrete) growth of the population dynamics links up the dimensions of the population between the time $\mathrm{t}$ and the previous times, $\mathrm{t}-1$ and $\mathrm{t}_{\mathrm{o}}$ (initial time) :

$$
\mathrm{N}_{\mathrm{t}}=\mathrm{N}_{\mathrm{t}-1} \mathrm{R} \text { or } \mathrm{N}_{\mathrm{t}}=\mathrm{N}_{0} \mathrm{R}^{\mathrm{t}}
$$

where, $\mathrm{R}$ - is the net rate of natural increase per individual (Begon et al. 1996).

The geometric progression of the (continuous) growth of populations, generally accepted, is that of the Malthusian or exponential growth (Pielou 1974, Begon et al. 1996) :

$$
\mathrm{N}_{\mathrm{t}}=\mathrm{N}_{\mathrm{t}-1} \mathrm{e}^{\mathrm{r}} \text { or } \mathrm{N}_{\mathrm{t}}=\mathrm{N}_{0} \mathrm{e}^{\mathrm{rt}}
$$

where, $N_{t}$ - is the number of individuals of the population, present at time $t ; \mathrm{N}_{\mathrm{t}-1}$ and $\mathrm{N}_{\mathrm{o}}$ - the number of individuals present at times $\mathrm{t}-1$ and $\mathrm{t}_{\mathrm{o}}$ (initial population); and $\mathrm{r}-$ is the intrinsic rate of natural increase of the population.

This exponential model is, to some extent, more general once it includes both the geometrical model of ratio $\mathrm{Q}$ and the one of rate $\mathrm{R}$ (Table 3 ).

Always based on the example of the multiplication of the Protista, Vernadsky (1925a $\$ \$ 68-70)$ introduces the notion of doubling period,

$$
\tau=\frac{1}{\mathrm{D}}
$$

and another way to estimate, with respect to time, the number of organisms formed:

$$
2^{\Delta-1}=\alpha
$$

where $\alpha$-is the daily increase of the number of individuals per individual, which "can be taken as a measure of the pressure of the living matter in the biosphere" (Vernadsky 1925b). Thus,

$$
\mathrm{N}_{\mathrm{n}}=2^{\mathrm{n} \Delta}=(\alpha+1)^{\mathrm{n}}
$$


Table 3. Multiplication of living beings, according two models of population growth: 1) Geometrical progression of ratio $\mathrm{Q}=2, \mathrm{~N}_{\mathrm{t}}=$ $\mathrm{N}_{\mathrm{o}} \mathrm{Q}^{\Delta t}$; 2) Exponential growth, $\mathrm{N}_{\mathrm{t}}=\mathrm{N}_{\mathrm{o}} \mathrm{e}^{\mathrm{rt}}$ or $\mathrm{N}_{\mathrm{t}}=\mathrm{N}_{\mathrm{o}} \mathrm{e}^{\mathrm{rt} t}$, taking into account the number of generations by day.

\begin{tabular}{lllcll}
\hline $\begin{array}{l}\text { Time } \\
(\mathrm{d})\end{array}$ & $\begin{array}{l}\text { Generations } \\
\mathrm{d}^{-1}(\text { no. })\end{array}$ & $\begin{array}{l}\text { Geometrical ratio } \\
(*)\end{array}$ & $\begin{array}{l}\text { Population } \\
\text { (no. of individuals) }\end{array}$ & Rate of increase & \multicolumn{1}{c}{$\begin{array}{l}\text { Population } \\
\text { (no. of individuals) }\end{array}$} \\
\hline $\mathrm{t}$ & $\Delta$ & $\mathrm{Q}$ & $\mathrm{N}_{\mathrm{o}} / \mathrm{N}_{\mathrm{t}}$ & $\begin{array}{l}\mathrm{R}=\ln N_{\mathrm{t}}-\operatorname{lnN}_{\mathrm{t}-1} \\
(* *)\end{array}$ & $\begin{array}{l}\mathrm{N}_{\mathrm{o}} / \mathrm{N}_{\mathrm{t}} \\
\mathrm{a}-\mathrm{b}\end{array}$ \\
& $\mathrm{a}-\mathrm{b}$ & $(\mathrm{R})$ & $1-1$ & - & $1-1$ \\
0 & - & - & $2-16$ & $0.693\left({ }^{* * *}\right)$ & $1.99-15.99$ \\
1 & $1-4$ & 2 & $4-256$ & 0.693 & $3.99-255.70$ \\
2 & $1-4$ & 2 & $8-4098$ & 0.693 & $7.99-4088.77$ \\
3 & $1-4$ & 2 & $16-65536$ & 0.693 & $15.99-65381.85$ \\
4 & $1-4$ & 2 & & & \\
\hline
\end{tabular}

$\left({ }^{*}\right)$ Net rate of natural increase $(\mathrm{R})$.

$\left.{ }^{* *}\right)$ Cf. Cancela da Fonseca 1980.

$\left({ }^{* *}\right)$ The difference between the number of individuals present in the population estimated by the exponential model and the one estimated by the geometrical progression model is due to the calculated degree of accuracy of the increasing rate; thus, for a value of $\mathrm{r}=0.69314718$ and of $\Delta=1, \mathrm{~N}_{4}=15.9999999$, and for $\Delta=4, \mathrm{~N}_{4}=65535.9994$; if the value taken $\mathrm{r}=0.6931472, \mathrm{~N}_{4}$ will respectively, $\mathrm{N}_{4}=16.0000012$ and $\mathrm{N}_{4}=65536.0204$.

$(\alpha+1)^{\mathrm{n}}$ - given the number of individuals, and

$$
\alpha=2^{\Delta}-1=\frac{\mathrm{N}_{\mathrm{n}}-\mathrm{N}_{\mathrm{n}-1}}{\mathrm{~N}_{\mathrm{n}-1}}
$$

(for instance, for $\mathrm{t}=4$ and $\Delta=4, \alpha=\left(2^{4}-1\right)=15$ or $\alpha=\left(\mathrm{N}_{4}-\mathrm{N}_{3}\right)$ ) $\mathrm{N}_{3}=(65536-4098) / 4098=14.99$, and $\mathrm{N}_{4}=(15+1)^{4}=65536$; Table 3).

The author considers, however, that "the representation of this phenomenon by $\alpha$ is much more real that the one represented by $\Delta$, because the $\Delta$, number of doublings, does not correspond to the natural phenomenon - the generation - in the context of cellular divisions"; while " $\alpha$ corresponds always to a natural phenomenon - that of the increasing number of individuals per day", though only per individual (Vernadsky 1925a \$70).

Always with the objective of establishing the relationship between living matter expansion and the biosphere, that is, the movement (every organism which reproduces itself, constitutes a movement) of the living matter spreading out over the surface of the biosphere, Vernadsky introduces two new constants: "the time (expressed in days of $24 \mathrm{~h}$ ) that an organism needs to colonize completely the surface of the Earth" $(\varepsilon)$; and the speed of this spread out movement, or "speed of transmission of life" (V), expressed in centimetres per second (Vernadsky 1925a $\$ \$ 82-83,1926 a / 1998$ and $1929 \$ \$ 37,41)$ :

$$
\mathrm{V}=\frac{(46383.93)(\log 2)(\Delta)}{18.70762-\log \mathrm{K}} \mathrm{cm} / \mathrm{s}
$$

This expression $\mathrm{V}$ applies for all organisms. According to Vernadsky (1926b, c),

$$
\mathrm{V}=\frac{\mathrm{E}}{\varepsilon} \mathrm{cm} / \mathrm{d}
$$

or

$$
\mathrm{V}=\frac{\mathrm{E}}{86400 \varepsilon} \mathrm{cm} / \mathrm{s}
$$

where

$$
\varepsilon=\frac{\log S-\log K}{\Delta \bullet \log 2}=\frac{18.70762-\log K}{\Delta \bullet \log 2},
$$

$\mathrm{S}=5.10065 \times 10^{18} \mathrm{~cm}^{2}$ is the Earth's surface and $\mathrm{E}=$ $4.0075721 \times 10^{9} \mathrm{~cm}$ is the Earth's equator dimension; then

$$
\mathrm{V}=\frac{4.0075721 \times 10^{9} \bullet \Delta \bullet \log 2}{86400(18.70762-\log \mathrm{K})}=46383.93 \times \frac{\Delta \cdot \log 2}{18.70762-\log \mathrm{K}} \mathrm{cm} / \mathrm{s}
$$

In this way, an estimation of the "kinetic geochemical energy of living matter" can be made by the formula $e=$ $\mathrm{PV}^{2} / 2$, a function of the organism's weight $(\mathrm{P})$ and the "speed of transmission of life" (V), which is a function of the organisms size ( $\mathrm{K}$, coefficient of density of life), and the intensity of multiplication $(\Delta)$ (Vernadsky 1925a $\$ \$ 88-$ $91,102,1926 \mathrm{a} / 1998,1926 \mathrm{~b}, \mathrm{c}$, and $1929 \$ \$ 37,40-41)$.

"The time needed for the occupation of the whole surface of the Earth is evidently a function of multiplication, because it is smaller when the number of the formed organisms is higher" (Vernadsky 1925a \$83).

This implies that "multiplication takes place in the limits of our planet and never can overtake them" (Vernadsky 1925 a $\$ 85,1926 a / 1998$ and $1929, \$ 30)$.

The maximum speed observed in the biosphere is that of the smallest organisms, the bacteria, speed that, according to Vernadsky $(1925$ a $\$ 96,1926 c, 1927)$ is very near of the speed of the sound in the atmosphere $\left(33100 \mathrm{~cm} \mathrm{~s}^{-1}\right)$.

For the author, "this coincidence cannot be accidental" and that "exists a deep primordial relationship between the 
multiplication of the organisms and their gaseous exchange" (Vernadsky 1925a \$96). Because "their gaseous exchange is the most characteristic manifestation of multiplication, and consequently of the transmission of the geochemical energy of life in the biosphere" (Vernadsky 1926b).

This "relationship between the multiplication of the organisms and their gaseous exchange", was stated from considerations over: a) on one hand, the speed of propagation of life for bacteria near of the speed of the sound (33 $100 \mathrm{~cm} \mathrm{~s}^{-1}$ ); and, b) on the other hand, the relation between the minimal dimensions of the bacteria (diameter up to $5 \times 10^{-5} \mathrm{~cm}$ ) and the minimal distances between the gaseous molecules $\left(\mathrm{ca} 10^{-7} \mathrm{~cm}\right)$. This statement is one of the most interesting and fundamental ideas of Vernadsky (1925a $\$ \$ 96-101)$.

In reality, respiration is one of the essential phenomena of the life of the living beings (Vernadsky 1926a/1998 and $1929 \$ 91)$. Its role is summed up by Vernadsky (1926b) this way: "respiration rules the propagation of life and determines the dimensions of the organisms and their faculty of multiplication".

One is then facing the concept of the geochemical energy of living matter, which is studied in terms of the kinetic energy of the multiplication movement (Vernadsky 1925a $\$ \$ 105-111)$.

To determine this energy, one needs to know the mass, then the average weight of the organism, or, if absent, its volume and density (Vernadsky 1925a $\$ \$ 102-104)$.

Vernadsky's biosphere approach is above all empirical. As he himself points out several times in "La Géochimie", most of his statements had already been made or had been suggested specifically by other authors. But his merit is that he was able to integrate all the scattered information he knew in a coherent and dynamic vision of the Earth's system (cf. Ghilarov 1995). The last two paragraphs of "The Biosphere" sum up quite well his thought: it follows ... that life presents an indivisible and indissoluble whole, in which all parts are interconnected both among themselves and with the inert medium of the biosphere. [...] The principal fact is that the biosphere has existed throughout all geological periods, from the most ancient indications of the Archean. In its essential traits, the biosphere has always been constituted in the same way. One and the same chemical apparatus, created and kept active by living matter, has been functioning continuously in the biosphere throughout geological time, driven by the uninterrupted current of radiant solar energy. This apparatus is composed of definite vital concentrations which occupy the same places in the terrestrial envelopes of the biosphere, while constantly being transformed. These vital films and concentrations form definite secondary subdivisions of the terrestrial envelopes. They maintain a generally concentric character, though never covering the whole planet in an uninterrupted layer. They are the planet's active chemical regions and contain the diverse, stable, dynamic equilibri- um systems of the terrestrial chemical elements. These are the regions where the radiant energy of the sun is transformed into free, terrestrial chemical energy. These regions depend, on the one hand, upon the energy they receive from the sun; and on the other hand, upon the properties of living matter, the accumulator and transformer of energy. The transformation occurs to different degrees for different elements, and the properties and the distribution of the elements themselves play an important role (Vernadsky 1926a/1998 and 1929, \$159).

All living concentrations are closely related to one another, and cannot exist independently. The link between these living films and concentrations, and their unchanging character throughout time, is an eternal characteristic of the mechanism of the Earth's crust. The land and the ocean have coexisted since the most remote geological times. This coexistence is basically linked with the geochemical history of the biosphere, and is a fundamental characteristic of its mechanism. From this point of view, discussions about the marine origin of continental life seem vain and fantastic. Life remains unalterable in its essential traits throughout geological times, and changes only in form. All the vital films (plankton, bottom, and soil) and all vital concentrations (littoral, sargassic, and fresh water) have always existed. Their mutual relationships, and the quantities of matter connected with them, have changed from time to time; but these modifications could not have been large, because the energy input from the sun has been constant, or nearly so, throughout geological time, and because the distribution of this energy in the vital films and concentrations can only have been determined by living matter - the fundamental part, and the only variable part, of the thermodynamic field of the biosphere. But living matter is not an accidental creation. Solar energy is reflected in it, as in all its terrestrial concentrations. We could push this analysis further, ... (Vernadsky $1926 \mathrm{a} / 1998$ and $1929 \$ 160$ ).

In any case, Vernadsky forgets Man. Civilized man is the "latest manifestation of life" and "tends to increase the size of the biosphere" (Vernadsky 1926a/1998 and 1929 $\$ 115,1945 b)$. His geochemical influence is quite important. "Civilized humanity has introduced changes into the structure of the [living] film on land which have no parallel in the hydrosphere. These changes are a new phenomenon in geological history, and have chemical effects yet to be determined. One of the principal changes is the systematic destruction, during human history, of forests, the most powerful parts of the [living] film" (Vernadsky 1926a/ 1998 and 1929 \$151). Again, Vernadsky was ahead of his time, forecasting some of the serious problems humanity faces nowadays (cf. McNemanin, in Vernadsky 1926a/ $1998 \$ 151)$.

Also, during his sojourn in Paris in 1922-1926, from his exchange of views with the mathematician Edouard Le Roy and the paleontologist Pierre Teilhard de Chardin, Vernadsky (1945b) adopts and develops the concept of 
noösphere, logical follow-up from that of biosphere: "noösphere following to biosphere" (Le Roy 1927).

This new concept of noosphère (du grec: $v o o \zeta=$ esprit $+\sigma \varphi \alpha i \rho \alpha=$ sphère), as "the stage through which the biosphere is now passing geologically" ["la phase par laquelle la biosphère est en train de passer, du point de vue géologique"], was introduced by Le Roy in his lectures at the Collège de France in Paris in 1925-26 (Le Roy 1927).

That way, "man by his work [...] is remaking [...] the biosphere $[\ldots]$ transforming it into a new geological state, the noösphere" which is thus "a new geological phenomenon on our planet. In it for the first time man becomes a large-scale geological force. He can and must build the province of his life by his work and thought, rebuild it radically in comparison with the past. Wider and wider creative possibilities open before him" (Vernadsky 1944, 1945b)

Vernadsky attains then the peak of his philosophical and biogeochemical scientific life with the writing up, in 1938, of his remarkable book, "Scientific thought as a planetary phenomenon" (in Russian), published for the first time in Russian, in an abreviated version in 1977 (according to Yashin and Yashina in Vernadsky 1991/1997) and later on in 1991 (in Russian) and in 1997 (in English) (Vernadsky 1991/1997), at least, in an edition conform to the author's original version (Guegamian pers. comm.).

Acknowledgements - We wish to thank Nevraumont Publishing Company New York for the permission to use the quotation, in English, from their book "The Biosphere" (1998), as well as Springer for the permission to reproduce Table 17 (p. 127) of the contribution of M. Taube to the Handbook of Environmental Chemistry, Vol. 1, Part F, 1992, ed. O. Huntzinger.

\section{References}

Allegre, C. J. and Michard, G. 1973. Introduction à la géochimie. - Presses Universitaires de France, Paris.

Anderson, J. M. 1981. Ecology for environmental sciences: biosphere, ecosystems and Man. - Edward Arnold, London.

Anon. 1997. The main dates of life and work of Academician V. I. Vernadsky. - In: Vernadsky V. I. (ed.), Scientific thought as a planetary phenomenon. Nongovernmental Ecological V. I. Vernadsky Foundation, Moscow, pp. 257-262.

Balandin, R. K. 1979. Vernadsky: life, thinking, immortality. Znanie, Moscow, in Russian.

Begon, M., Harper, J. L. and Townsend, C. R. 1996. Ecology. Individuals, populations and communities. 3rd ed. - Blackwell.

Cancela da Fonseca, J. P. 1980. Quelques approches analytiques en dynamique de populations édaphiques (Acariens Oribates). - Rev. Ecol. Biol. Sol 17: 445-477.

Cancela da Fonseca, J. P. 1982. Sur la dynamique des peuplements d'Acariens Oribates en milieu forestier. Aspects méthodologiques. - Ph.D. thesis, Univ. Paris-Sud, Paris XI.
Cancela da Fonseca, J. P. and Poinsot-Balaguer, N. 1983. Les régimes alimentaires des Microarthropodes du sol en relation avec la décomposition de la matière organique. - Bull. Soc. Zool. France 108: 371-388.

Clarke, F. W. 1908. The data of geochemistry. - Bull. U.S. Geol. Surv., Washington, D.C.

Cole, L. C. 1953. The Ecosphere. - Sci. Am. 198: 92-93.

Deléage, J. P. 1997. Wladimir Vernadsky, penseur de la biosphère. - In: Vernadsky W. (ed.), La biosphère [Préface]. Diderot Multimédia, Paris, pp. 1-39; 279-282.

Déplanche, Y. 1991. Mémo formulaire. - Paris, Casteilla.

Duvignaud, P. 1980. La synthèse écologique. 2nd ed. - Doin, Paris.

Fyfe, W. S. 1992. Geosphere interactions on a convecting planet: mixing and separation. - In: Hutzinger O. (ed.), The handbook of environmental chemistry; Vol. 1, Part F, The natural environment and the biogeochemical cycles. - Springer, pp. $1-26$.

Ghilarov, A. M. 1995. Vernadsky's biosphere concept: an historical perspective. - Quart. Rev. Biol. 70: 193-203.

Grinevald, J. 1997a. Cronología bio-bibliográfica de V. I. Vernadsky. - In: Vernadsky V. I.(ed.), La Biosfera. Fundación Argentaria, Visor Dis., Madrid, pp. 21-37.

Grinevald, J. 1997b. Vladimir Ivanovich Vernadsky (18631945). A biographical chronology. - In: Vernadsky V. I.(ed.), The Biosphere. A Peter N. Nevraumont Book, Copernicus/ Springer, pp. 151-158.

Guegamian, G. V. 1980. On V. I. Vernadsky biospherology. Zhurnal Obshchei Biologii 41: 581-595, in Russian.

Guegamian, G. V. 1981. Lamarck, Vernadsky et la Biosphèrologie. - Priroda 9: 78-81, in Russian.

Hutchinson, G. E. 1944. W. I. Vernadsky, problems of biogeochemistry - II. - Trans. Conn. Acad. Arts Sci. 35: 483-517.

Hutchinson, G. E. 1970. The biosphere. - Sci. Am. 223: 45-53.

Hutton, J. 1788. Theory of the Earth. - Trans. Roy. Soc. Edinburgh 1: 209-304.

Krout, I. V. 1983. Vladimir Ivanovich Vernadsky 1863-1945. Geographers: Bibliogr. Stud. 7: 135-144.

Lamarck, J. B. 1802. Hydrogéologie. - Chez l'Auteur, Paris. (1964: Hydrogeology, English translation by A. V. Carozzi. Univ. of Illinois Press, Urbana).

Lapo, A. V. 1982. Traces of bygone biospheres. - (1979: English translation of Russian ed. by V. Purto. Mir Publishers, Moscow).

Le Roy, E. 1927. L'exigence idéaliste et le fait de l'évolution. Boisvin, Paris.

Lindeman, R. L. 1942. The trophic-dynamic aspect of ecology. Ecology 23: 399-418.

Lovelock, J. E. 1979. Gaia: a new look at life on earth. - Oxford Univ. Press.

Lovelock, J. E. 1988. The ages of Gaia: a biography of our living Earth. - W. W. Norton, New York and Oxford Univ. Press.

Margulis, L. and Lovelock, J. E. 1989. Gaia and geognosy. - In: Rambler, M. B., Margulis, L. and Fester, R. (eds), Global ecology. Towards a science of the biosphere. Academic Press, pp. 1-30.

Mauguin, C. 1945. Notice nécrologique sur Wladimir Vernadsky. - Comptes rendus de l'Académie des Sciences, Paris 221: 157-161. 
Moreau, J. L. 1805. Oeuvres de Vicq-d'Azyr recueillies et publées avec des notes et un discours sur sa vie et ses ouvrages. - Chez L. Dupent-Duverger, Paris.

Odum, E. P. 1959. Principles of ecology. 2nd ed. - W. B. Saunders.

Pielou, E. C. 1974. Population and community ecology: principles and methods. - Gordon and Breach, New York.

Rambler, M. B., Margulis, L. and Fester, R. 1989. Global ecology. Towards a science of the biosphere. - Academic Press.

Ridley, M. 1993. Evolution. - Blackwell.

Rihani, M., Cancela da Fonseca, J. P. and Kiffer, E. 1995. Decomposition of beech leaf litter by microflora and mesofauna. II. Food preferences and action of oribatid mites on different substrates. - Eur. J. Soil Biol. 31: 67-79.

Schlesinger, W. H. 1997. Biogeochemistry: an analysis of global change. 2nd ed. - Academic Press.

Suess, E. 1875. Die Entschung der Alpen [The Origin of the Alps]. - Wilhelm Braumüller, Wien.

Taube, M. 1992. Evolution of matter and energy. - In: Hutzinger O. (ed.), The handbook of environmental chemistry; Vol. 1, Part F, The natural environment and the biogeochemical cycles. Springer, pp. 65-182.

Vernadsky, W. 1924a. La Géochimie. - Félix Alcan, Paris.

Vernadsky, W. 1924b. Sur la représentation de la composition chimique de la matière vivante. - Comptes rendus de l'Académie des Sciences, Paris 179: 1215-1217.

Vernadsky, W. I. 1925a. La matière vivante dans la biosphère. (Mss. dactylograhié). - Bourg la Reine.

Vernadsky, W. 1925b. Sur la pression de la matière vivante dans la biosphère. -Comptes rendus de l'Académie des Sciences, Paris 180: 2079-2081.

Vernadsky, V. I. 1926a. Biosfera. Nauchnoe Khimikoteknicheskoe Izdatelstvo. -Leningrad, in Russian. (1998: translated ed. by Langmuir, D. B. Peter N. Nevraumont Book, Copernicus/Springer).

Vernadsky, W. 1926b. Sur la multiplication des organismes et son rôle dans le mécanisme de la biosphère. - Revue Générale des Sciences 37(23): 661-668; 37: 700-708.
Vernadsky, W. 1926c. Études Biogéochimiques. I. Sur la vitesse de la transmission de la vie dans la biosphère. - Bulletin de l'Académie des Sciences de l'URSS 20: 727-744.

Vernadsky, W. 1927. Études Biogéochimiques. II. La vitesse maximum de la transmission de la vie dans la biosphère. Bulletin de l'Académie des Sciences de l'URSS 21: 241-254.

Vernadsky, W. 1929. La Biosphère. - Félix Alcan, Paris. (1986: The Biosfera, abridged version. Synergetic Press, London. 1997: La Biosphère, Diderot, Paris).

Vernadsky, W. 1930. Considérations générales sur l'étude de la composition chimique de la matière vivante. - Travaux du Laboratoire de Biogéochimie près de l'Académie des Sciences de l'URSS, Leningrad 1: 5-32.

Vernadsky, W. I. 1944. Problems of biogeochemistry - II. Trans. Conn. Acad. Arts Sci. 35: 483-517.

Vernadsky, W. I. 1945a. La biogéochimie. - Scientia 78: 77-84.

Vernadsky, W. I. 1945b. The biosphere and the noösphere. - Am. Sci. 33: 1-12.

Vernadsky, W. I. 1965. Chemical structure of biosphere of the earth and its surroundings. - Nauka, Moskva, in Russian.

Vernadsky, V. I. 1991. Scientific thought as a planetary phenomenon. - Nauka, Moskva, in Russian. (1997: translated ed. by Starostin B. A. Nongovernmental Ecological V. I. Vernadsky Foundation, Moscow).

Vernadsky, W. I. 1994. Living matter and biosphere. - Nauka, Moskva, in Russian. (Russian translation of 1925a manuscript).

Vernadsky, W. and Vinogradoff, A. 1931. Sur la composition chimique des Lemna comme caractéristique des espèces. Comptes rendus de l'Académie es Sciences, Paris 193: 560561.

Watson, J. D. and Crick, F. H. C. 1953a. Molecular structure of nucleic acids: a structure for deoxyribose nucleic acid. - Nature 171: 737-738.

Watson, J. D. and Crick, F. H. C. 1953b. Genetical implications of the structure of deoxyribonucleic acid. - Nature 171: 964-967. 